\title{
Advance on anti-diabetic effects of protein hydrolysates and peptides derived from cereals and pseudocereals
}

\author{
Weijing $\mathrm{Wu}^{1}$, Wen Xie ${ }^{1}$, Qianglai Tan ${ }^{1}$, Lanlan $\mathrm{Wu}^{1}$, Shanshan $\mathrm{Zhu}^{1}$, Hong $\mathrm{Zhu}^{2}$, and Ju Qiu,** \\ ${ }^{1}$ Xiamen Medical College, 361000, China; \\ ${ }^{2}$ Institute of Food and Nutrition Development, Ministry of Agriculture and Rural Affairs, 100081, China
}

\begin{abstract}
Diabetes is a complex and heterogeneous disorder disease with elevated blood glucose, which is one of the most serious global public health problems. Cereals and pseudocereals, as staple food, are major sources of dietary protein. Cereal and pseudocereal proteins are potential sources of food-derived bioactive peptides and proposed to prevent and ameliorate diabetes. According to recent researches, this review summaries the isolation, purification and analysis of anti-diabetic protein hydrolysates and peptides from cereals and pseudocereals. In addition, their anti-diabetic activities and mechanisms were reviewed by in vitro inhibition of carbohydrate digestive enzyme and dipeptidyl peptidase-IV, in vivo hypoglycaemic effects, and glucose homeostasis in cell model.
\end{abstract}

\section{Introduction}

Diabetes is a complex chronic metabolic disease characterized by hyperglycaemia. It is one of the most serious public health problems in the world, severely endangering human health [1]. The cause of diabetes may be attributed to insufficient insulin secretion or insulin resistance [1]. In addition to the genetic predisposition, unhealthy diet and physical inactivity are important factors leading to type 2 diabetes [2]. Therefore, dietary regulation plays a vital role in the prevention and early treatment of diabetes. The drugs used for type 2 diabetes can maintain the blood glucose homeostasis by promoting insulin secretion, improving insulin sensitivity, or delaying the absorption of carbohydrates in the intestine and improving the absorption and utilization of glucose [1]. Furthermore, alleviation of oxidative stress and inflammation associated with diabetes also contributes to the regulation of glucose homeostasis [3, 4]. However, the drugs currently used for treating diabetes exhibit diverse adverse effects. Therefore, the development of natural food-derived peptides may not only avoid the side effects based on their natural sources but may also allow the early intervention and nutritional treatment of patients, consequently presenting an ideal choice for preventing and improving diabetes.

As a staple food, cereals and pseudocereals are primary sources of dietary protein, which are abundant and cheap protein sources. In vitro studies have shown that proteins and their hydrolysates from cereals and pseudocereals are involved in a variety of biological activities, including antioxidant, anti-hypertensive, anticancer, anti-thrombosis activities and various other properties $[5,6]$. The cereal protein, such as millet protein [7], showed anti-diabetic properties. In addition, the screening of anti-diabetic protein hydrolysates and peptides from cereals and pseudocereals are of substantial significance for exploring functional peptides preventing and treating diabetes via dietary regulation.

This paper reviews the isolation, purification, and analysis techniques of anti-diabetic protein hydrolysates and peptides derived from cereals and pseudocereals. The antidiabetic potentials of protein hydrolysates and peptides may via one or more mechanisms, such as in vitro inhibition of carbohydrate digestive enzymes, in vitro inhibition of the dipeptyl peptidase IV (DPP-IV), decrease in blood glucose levels in vivo studies, and the regulation mechanisms in cell model. In addition, antidiabetic effects of protein hydrolysates and peptides related to their structural characteristics are discussed. This study provides approaches for screening hypoglycaemic peptides from cereals and pseudocereals and examining their anti-diabetic mechanisms.

\section{Isolation, purification and analysis of hydrolysates and peptides from cereal and pseudocereal proteins}

The protein content of cereals and pseudocereals is generally $7-15 \%$. The alkaline extraction with isoelectric precipitation is most used for extracting protein from cereals and pseudocereals, while proteins can be also precipitated by ammonium sulphate. The Osborne method can be used to extract water-soluble albumin, salt-soluble globulin, alcohol-soluble prolamin, and alkali-soluble glutenin [9-11], which can be utilized to classify the activities of four proteins and screen for highly active components. In addition, starches and other complex polysaccharides in cereals and pseudocereals can be removed by corresponding enzymes before extraction, thus improving the protein yield.

Corresponding author: qiuju@ @aas.cn 
The study of protein hydrolysates and peptides is an effective way to analyse the physiological activities of cereal and pseudocereal proteins while screening and synthesizing the active fragments for industrial applications. The analysis of structural characterizations and physiological activities of active peptides are highly significant for the promotion of human health. The general process used for studying the active hypoglycaemic protein hydrolysates and peptides from cereals and pseudocereals is shown in Fig. 1. By combining trypsin with pepsin, simulated gastrointestinal digestion (SGID) is commonly used to explore how cereal and pseudocereal proteins function in the body after digestion. As other food components may interfere with the digestion of proteins, it is necessary to use specific proteases for hydrolysis, such as commercial enzymes of microbial or plant origin, to release specific active peptides. Temperature [12], time [13], enzyme type [14-16], and other conditions can affect the degree of protein hydrolysis and the cleavage site, thus impacting the sequence and activity of the peptides. Ultrasonic assisted protein hydrolysis can also be used to promote the protein hydrolysis by exposing active groups and improving the efficiency of enzymatic hydrolysis [17]. In addition, protein is also hydrolysed by microbial fermentation, such as lactic acid bacterial [18, 19]. Different from other food-derived peptides, cereals and pseudocereals can promote protein hydrolysis by activating endogenous proteases via germination [19].

The characterization of protein hydrolysates can be described by molecular weight distribution and amino acid analysis. However, the analysis of the structural sequences of the active peptides requires further purification and separation. The separation of the active peptides can be based on differences in molecular weight (ultrafiltration and gel chromatography), charge (ionexchange chromatography), and hydrophobicity (reverse high-performance chromatography). The structure of peptides is mainly characterized by their amino acid sequences via mass spectrometry. After the identification of peptide sequence, it can be compared with the known active peptide sequence in a bioinformatics bank (like BIOPEP) for prediction or verification of the specific mechanism of hypoglycaemia. Computer simulation of the protein hydrolysis process is also used to predict the possibility of producing active peptides from specific proteins [20]. Furthermore, the interactions between peptides and enzymes can be determined using the computational molecular docking method via in silico approach, thus revealing their inhibitory activity and mechanism [21]. Then, peptides are synthesized according to identified amino acid sequence, and its exact activity is then determined. However, synthetic peptides are less active than natural peptides.

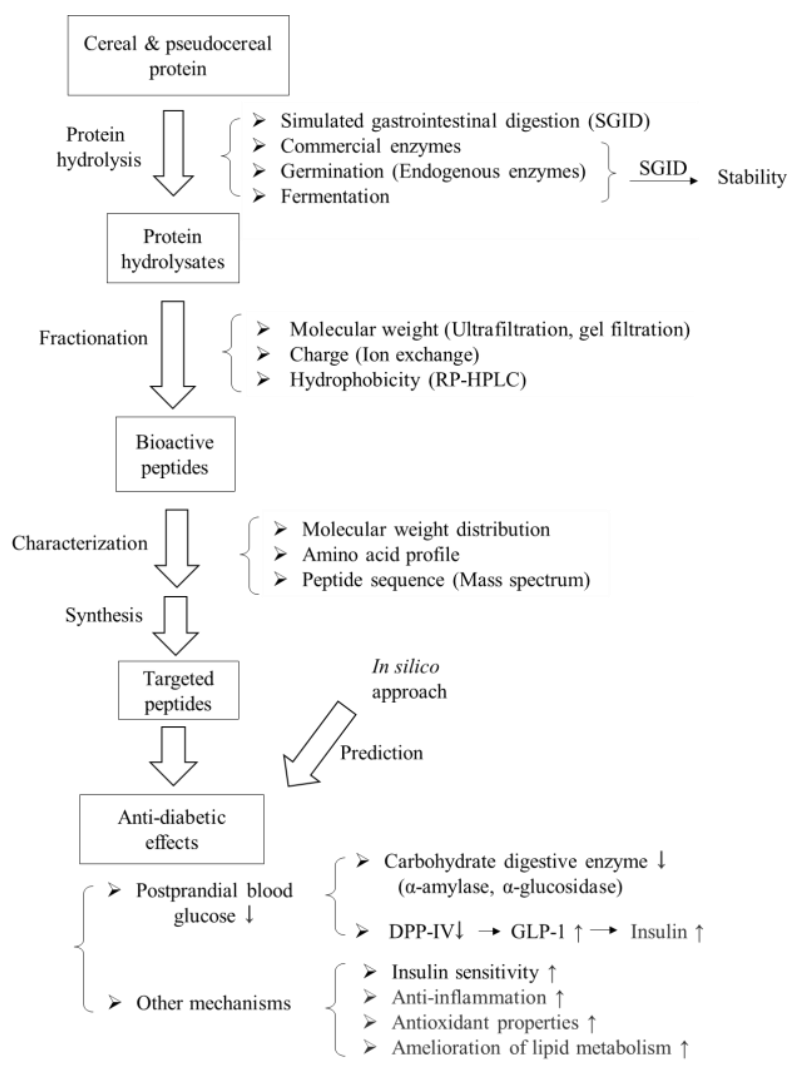

Fig. 1. Flow diagram for isolation and characterization of antidiabetic protein hydrolysates and peptides from cereals and pseudocereals.

\section{Effects and mechanisms of cereal and pseudocereal protein hydrolysates and peptides in maintaining blood glucose homeostasis}

Protein hydrolysates and peptides can inhibit the activities of carbohydrate digestive enzymes in the intestine, such as $\alpha$-glucosidase and $\alpha$-amylase, thereby interfering with glucose absorption and reducing blood glucose after meals. Moreover, they can inhibit the DPPIV enzyme and promote glucagon-like peptide-1 (GLP-1) secretion and insulin secretion, thus controlling a rise in blood glucose after meals. Furthermore, they assist to regulate glucose metabolism in peripheral tissues and maintain blood glucose homeostasis by improving insulin sensitivity, reducing inflammatory response, and facilitating antioxidant effects [22]. Although hypoglycaemic effect of active cereal peptides is not as effective as that of commercial drugs, their safety and source abundance render them beneficial in exerting long-term glycaemic control through dietary supplementation and intake.

\subsection{Enzyme inhibition activity}

\subsubsection{Carbohydrate digestive enzyme inhibition activity}

Carbohydrates are first degraded by a -amylase during gastrointestinal digestion, after which they are degraded 
by $\alpha$-glucosidase in the mucosa of the small intestine and absorbed into the blood. Carbohydrate digestive enzyme inhibitors, such as acarbose, are an important strategy for

Table 1 Cereal and pesudocereal protein hydrolysates and peptides with in vitro inhibitory activities against

\begin{tabular}{|c|c|c|c|c|c|c|c|}
\hline $\begin{array}{l}\text { Protein } \\
\text { source }\end{array}$ & Enzyme(s) used & Inhibitory activity & $\begin{array}{l}\text { Inhibition } \\
\text { Value of } \\
\text { hydrolysates }\end{array}$ & $\begin{array}{l}\text { Fractionation } \\
\text { method(s) }\end{array}$ & $\begin{array}{l}\text { Inhibition value } \\
\text { after fractionation }\end{array}$ & $\begin{array}{l}\text { Peptide } \\
\text { identification }\end{array}$ & $\mathrm{e}(\mathrm{s})$ \\
\hline $\begin{array}{l}\text { Wheat } \\
\text { germ }\end{array}$ & Trypsin & $\alpha$-glucosidase & $\begin{array}{l}\mathrm{IC}_{50}=10.98 \\
\mathrm{mg} / \mathrm{mL}\end{array}$ & $\begin{array}{l}\text { Ultrafiltration } \\
(<5 \mathrm{kDa}) \rightarrow \\
\text { Ion exchange } \rightarrow \\
\text { Gel filtration } \rightarrow \\
\text { RP-HPLC }\end{array}$ & $\begin{array}{l}\mathrm{IC}_{50}=0.098 \\
\mathrm{mg} / \mathrm{mL}\end{array}$ & $\begin{array}{l}\text { Identified } 7 \text { peptides } \\
\text { including } 1 \text { dipeptide and } 6 \\
\text { tripeptides }\end{array}$ & [17] \\
\hline Rice bran & $\begin{array}{l}\text { Alcalase, } \\
\text { neutrase, } \\
\text { flavourzyme, } \\
\text { protamax }\end{array}$ & $\alpha$-glucosidase & $\begin{array}{l}7-53.5 \mu \mathrm{g} \text { acarbose } \\
\text { equivalent } / \mathrm{mg} \\
\text { protein }\end{array}$ & $\begin{array}{l}\text { Ultrafiltration } \\
(<3 \mathrm{kDa}) \rightarrow \\
\text { Ion exchange }\end{array}$ & & $\begin{array}{l}\text { Identified } 13 \text { peptides, and } 8 \\
\text { of these containing } \\
\text { sequences with } \alpha- \\
\text { glucosidase inhibitory } \\
\text { activity. }\end{array}$ & [10] \\
\hline Rice bran & SGID & $\alpha$-glucosidase & $\begin{array}{l}39.6-50.1 \mu \mathrm{g} \\
\text { acarbose } \\
\text { equivalent } / \mathrm{mg} \\
\text { protein }\end{array}$ & $\begin{array}{l}\text { Ultrafiltration } \\
(3,10 \mathrm{kDa}) \rightarrow \\
\text { Ion exchange }\end{array}$ & $\begin{array}{l}54.4 \mu \mathrm{g} \\
\text { acarbose } \\
\text { equivalent } / \mathrm{mg} \\
\text { protein }\end{array}$ & $\begin{array}{l}\text { Identified } 39 \text { peptides, and } \\
37 \text { of these contained } \\
\text { sequences with } \alpha \text { - } \\
\text { glucosidase inhibitory } \\
\text { activity. }\end{array}$ & [15] \\
\hline $\begin{array}{l}\text { Rice bran } \\
\text { albumin }\end{array}$ & Alcalase & $\alpha$-glucosidase & $\begin{array}{l}52.4 \mu \mathrm{g} \text { acarbose } \\
\text { equivalent } / \mathrm{mg} \\
\text { protein }\end{array}$ & $\begin{array}{l}\text { Ultrafiltration } \\
(3,10 \mathrm{kDa}) \rightarrow \\
\text { Ion exchange }\end{array}$ & $\begin{array}{l}65.1 \mu \mathrm{g} \text { acarbose } \\
\text { equivalent } / \mathrm{mg} \\
\text { protein }\end{array}$ & $\begin{array}{l}\text { Identified } 40 \text { peptides } \\
\text { containing sequences with } \\
\alpha \text {-glucosidase inhibitory } \\
\text { activity }\end{array}$ & [30] \\
\hline Quinoa & SGID & $\alpha$-glucosidase & $\begin{array}{l}\mathrm{IC}_{50}=1.45-1.81 \\
\mathrm{mg} / \mathrm{mL}\end{array}$ & $\begin{array}{l}\text { Ultrafiltration } \\
(<5 \mathrm{kDa}) \rightarrow \\
\text { RP-HPLC }\end{array}$ & $\begin{array}{l}\mathrm{IC}_{50}=0.86 \\
\mathrm{mg} / \mathrm{mL}\end{array}$ & $\begin{array}{l}\text { IQAEGGLT and } \\
\text { DKDYPK }\end{array}$ & [13] \\
\hline Quinoa & $\begin{array}{l}\text { Germination, } \\
\text { fermentation by } \\
\text { lactic acid } \\
\text { bacteria } \\
\text { (QLCSY13, } \\
\text { QLCZ) }\end{array}$ & $\alpha$-glucosidase & $\begin{array}{l}\mathrm{IC}_{50}=8.86 \\
\mathrm{mg} / \mathrm{mL} \\
(\mathrm{QLCSY} 13)\end{array}$ & $\begin{array}{l}\text { Ultrafiltration } \\
(<3 \mathrm{kDa}) \rightarrow \\
\text { RP-HPLC }\end{array}$ & $\begin{array}{l}\mathrm{IC}_{50}=6.6 \\
\mathrm{mg} / \mathrm{mL}(\mathrm{QLCZ} \\
\text { Fraction } 19) ; \\
\mathrm{IC}_{50}=10.39 \mathrm{mg} / \\
\mathrm{mL}(\mathrm{QLCSY} 13 \\
\text { Fraction } 18)\end{array}$ & $\begin{array}{l}3 \text { peptides in QLCSY } 13 \\
\text { fraction } 18 \text { and } 3 \text { peptides in } \\
\text { QLCZ fraction } 19 \text { contained } \\
\text { sequences with } \alpha \text { - } \\
\text { glucosidase inhibitory } \\
\text { activity }\end{array}$ & [19] \\
\hline $\begin{array}{l}\text { Brewer's } \\
\text { spent } \\
\text { (Barley) }\end{array}$ & $\begin{array}{l}11 \text { commercial } \\
\text { enzymes }\end{array}$ & $\alpha$-glucosidase & $\begin{array}{l}\text { Inhibition rate: } 63.5- \\
66.8 \% \\
(7.5 \mathrm{mg} / \mathrm{mL})\end{array}$ & & & & [25] \\
\hline $\begin{array}{l}\text { Brewer's } \\
\text { spent } \\
\text { (Barley) }\end{array}$ & Alcalase & $\alpha$-glucosidase & $\begin{array}{l}\text { Inhibition rate: } \\
21.4 \% \\
(4 \mathrm{mg} / \mathrm{mL})\end{array}$ & $\begin{array}{l}\text { Ultrafiltration } \\
(<5 \mathrm{kDa})\end{array}$ & $\begin{array}{l}\text { Inhibition rate: } \\
56.4 \% \\
(4 \mathrm{mg} / \mathrm{mL})\end{array}$ & & [29] \\
\hline Corn germ & $\begin{array}{l}\text { Flavourzyme, } \\
\text { trypsin, alcalase }\end{array}$ & a -glucosidase & $\begin{array}{l}\text { Inhibition rate: } 15.9- \\
41.3 \% \\
(20 \mathrm{mg} / \mathrm{mL})\end{array}$ & $\begin{array}{l}\text { Ultrafiltration } \\
(2,10 \mathrm{kDa})\end{array}$ & $\begin{array}{l}\text { Inhibition rate: } \\
15.9-41.3 \% \\
(20 \mathrm{mg} / \mathrm{mL})\end{array}$ & & [47] \\
\hline Rice bran & $\begin{array}{l}\text { Flavourzyme, } \\
\text { trypsin, alcalase, } \\
\text { protamax }\end{array}$ & $\alpha$-amylase & $\begin{array}{l}6.9-56.2 \mu \mathrm{g} \\
\text { acarbose } \\
\text { equivalent /mg } \\
\text { protein }\end{array}$ & & & & [10] \\
\hline Quinoa & SGID & $\alpha$-amylase & $\begin{array}{l}\mathrm{IC}_{50}=0.19-0.53 \\
\mathrm{mg} / \mathrm{mL}\end{array}$ & $\begin{array}{l}\text { Ultrafiltration } \\
(<5 \mathrm{kDa}) \rightarrow \\
\text { RP-HPLC }\end{array}$ & $\begin{array}{l}\mathrm{IC}_{50}=0.42 \\
\mathrm{mg} / \mathrm{mL}\end{array}$ & GEHGSDGNV & [13] \\
\hline Corn germ & $\begin{array}{l}\text { Flavourzyme, } \\
\text { trypsin, alcalase }\end{array}$ & $\alpha$-amylase & $\begin{array}{l}\text { Inhibition rate: } \\
>50 \% \\
(10 \mathrm{mg} / \mathrm{mL})\end{array}$ & $\begin{array}{l}\text { Ultrafiltration } \\
(2,10 \mathrm{kDa})\end{array}$ & $\begin{array}{l}\text { Inhibition rate: } \\
37.5-71.3 \% \\
(10 \mathrm{mg} / \mathrm{mL})\end{array}$ & & [47] \\
\hline
\end{tabular}

control of the diabetes, helping to delay carbohydrate absorption and control blood glucose after meals [23]. However, these drugs have side effects like abdominal *without IC50 value 
pain, flatulence, and diarrhea [24]. Cereals and pseudocereals contain 60-80\% carbohydrates, which are critical in glycemia control. Protein hydrolysates from cereals and pseudocereals with inhibitory activities against carbohydrate digestive enzyme show the unique advantage over that from other food sources, because they function along with starch digestion, regulating the blood glucose in the digestion process.

Cereal and pseudocereal protein hydrolysates and peptides primarily inhibit $\alpha$-glucosidase, while few studies found the inhibitory activity of $\alpha$-amylase (Table $1)$. It has been reported that the ability of cereal and pseudocereal protein to inhibit $\alpha$-glucosidase can be improved by hydrolysis $[13,15,17,25]$. The inhibitory activity of cereal and pseudocereal protein hydrolysates against $\alpha$-glucosidase ranged from 1.45 to $10.98 \mathrm{mg} / \mathrm{mL}$ in $\mathrm{IC}_{50}$. Studies have also shown that rice bran protein hydrolysates do not affect $\alpha$-glucosidase [14], and peptides from oat globulin can even promote $\alpha$ glucosidase activity $[11,26]$. Some cereals, such as wheat and buckwheat, contain proteins that inhibit $\alpha$ amylase [8]. Through enzymatic hydrolysis, cereal protein hydrolysates can produce $\alpha$-amylase inhibitory activity [10, 13, 47]. Furthermore, cereal proteins and their hydrolysates can also interact directly with starch, reducing its digestibility by increasing the ordered structure of the starch molecules $[27,28]$. The inhibition effects of different cereal and pseudocereal protein hydrolysates against a -glucosidase and a -amylase are different, and their functional peptides remain unclear.

The inhibitory effect of cereal protein hydrolysates on enzymatic activity is closely related to the degree of hydrolysis and molecular weight of the hydrolysates. Ultrafiltration was used to enrich protein hydrolysates with low molecular weight, significantly improving their inhibitory activity. Generally, $3 \mathrm{kDa}, 5 \mathrm{kDa}$, and $10 \mathrm{kDa}$ are used as the screening criteria. The inhibition of $\alpha$ glucosidase activity by the small molecular components in cereal protein hydrolysates exceeded that of large molecular components [10,13,29,30], which may be related to the fact that the inhibition of $\alpha$-glucosidase by peptides typically involve 3-4 amino acids[35]. Since peptides with charge of 0 or +1 have higher $\alpha$ glucosidase inhibitory activity[31], ion exchange technique can significantly increase the $\alpha$-glucosidase inhibition activity of rice bran albumin hydrolysates, of which the neutral and positive peptides display the highest activity [15].

Identifying peptides are crucial for screening their active peptides and predicting their regulation of blood glucose homeostasis. As shown in Table 1, the enriched peptides with high activity were identified via mass spectrometry and then compared with the peptides already active in a database (such as BIOPEP) to predict the inhibitory activity of $\alpha$-glucosidase of peptides $[10,15,19,30]$. Peptides with $\alpha$-glucosidase inhibitory activity contain hydroxyl-containing amino acids at the N-terminal, such as Ser, Tyr, and Thr, or basic amino acids, such as Arg and Lys [31]. In addition, the presence of Pro in the amino acid chain or Ala or Met in the C-terminal indicates a higher glucosidase inhibitory activity [31].

Currently, synthetic peptides according to identified sequence from quinoa, IQAEGGLT and DKDYPK, have the inhibitory activity against $\alpha$-glucosidase at $250 \mu \mathrm{M}$, $55.85 \%$, and $22.16 \%$, respectively, while the level of inhibition of $\alpha$-amylase by GEHGSDGNV at $250 \mu \mathrm{M}$ is $30.84 \%$ [13].

\subsubsection{DPP-IV inhibition activity}

The consumption of food stimulates GLP-1, as well as the $\beta$-pancreatic cells to produce insulin, maintaining blood glucose homeostasis [32]. However, GLP-1 is easily degraded by DPP-IV, losing its biological activity. Therefore, DPP-IV enzyme inhibitors have attracted increasing attention in recent years. Diprotin A is one of the most effective DPP-IV enzyme inhibitors found to date, but it has side effects, such as weight gain [33]. DPP-IV inhibitory peptides, which have been extensively studied, are derived from casein and collagen [34]. The inhibitory activity of DPP-IV of hydrolysates from most milk protein was $<1.5 \mathrm{mg} / \mathrm{mL}\left(\mathrm{IC}_{50}\right)$ [35]. However, due to high consumption, the protein intake via cereals and pseudocereals far exceeds that from dairy products, indicating that DPP-IV inhibitory peptides derived from cereals and pseudocereals exhibit substantial application potential.

Cereal and pseudocereal proteins have no inhibitory effects on DPP-IV, but their hydrolysed products can significantly inhibit DPP-IV [12,25,36]. As shown in Table 2, the DPP-IV $\mathrm{IC}_{50}$ of protein hydrolysates and peptides from cereals and pseudocereals ranged from $0.12 \mathrm{mg} / \mathrm{mL}$ to $3.91 \mathrm{mg} / \mathrm{mL}$. The DPP-IV inhibitory activity of wheat gluten protein hydrolysates was further enhanced by SGID, indicating that the DPP-IV inhibitory activity of wheat peptides was stable during intestinal digestion [12]. After ultrafiltration, the inhibitory activity of the small molecular components significantly exceeded that of the large molecular components $[11,13]$.

The structure-activity relationship of the DPP-IV inhibitory peptides remains unclear. Generally, the specific amino acid sequence is the primary factor. Peptides have Ala or Pro at the N-terminal, which can directly compete with natural substrates for enzymatic activity sites [32]. Consequently, proteins with a Pro structure may be an excellent source of DPP-IV inhibitors, such as wheat gluten protein hydrolysate [12] and rice protein hydrolysates $[14,16]$. Molecular docking results also showed that oats displayed lower potential as a DPP-IV inhibitor compared with barley and wheat [34]. However, the activity of peptides with a Pro structure varies depending on the peptide segment in which they are linked. The DPP-IV inhibitory activity of dipeptide Ala-Pro was 19.4 times higher than that of IlePro (7.95 vs. $0.41 \mathrm{mM}$ ), while the dipeptide Gly-Pro showed no inhibitory activity [16]. Ile-pro, a dipeptide with high inhibitory activity, was identified in the protein hydrolysates of rice bran [16]. Additionally, noncompetitive inhibitors can bind to substrate recognition 
sites on the DPP-IV, leading to changes in substrate recognition and hydrolytic activity, and typically involves a longer peptide containing 13-15 peptides [32]. However, few studies exist regarding this type of inhibitory peptides from cereals and pseudocereals. Since the active centre of DPP-IV [32, 37], such as Ala and Pro, are hydrophobic, other hydrophobic amino acid

Table 2 Cereal and pesudocereal protein hydrolysates and peptides with in vitro inhibitory activities against DPP-

\begin{tabular}{|c|c|c|c|c|c|c|}
\hline \multicolumn{7}{|c|}{ IV } \\
\hline $\begin{array}{l}\text { Protein } \\
\text { source }\end{array}$ & Enzyme(s) used & $\mathrm{IC}_{50}$ & $\begin{array}{l}\text { Fractionation } \\
\text { method(s) }\end{array}$ & $\begin{array}{l}\text { IC } 50 \text { after } \\
\text { fractionation }\end{array}$ & Peptide identification & Reference(s) \\
\hline $\begin{array}{l}\text { Wheat } \\
\text { Gluten }\end{array}$ & $\begin{array}{l}\text { Debitrase } \\
\text { HYW20 } \\
\rightarrow \text { SGID }\end{array}$ & $\begin{array}{l}0.24-0.66 \\
\mathrm{mg} / \mathrm{mL}\end{array}$ & & & $\begin{array}{l}\text { Identified peptides with } \\
\text { DPP-IV inhibitory } \\
\text { sequences: Pro-Leu, Trp- } \\
\text { Leu, Trp-Pro. }\end{array}$ & [12] \\
\hline Oat & SGID, trypsin & $0.99 \mathrm{mg} / \mathrm{mL}$ & $\begin{array}{l}\text { Ultrafiltration } \\
(<3 \mathrm{kDa})\end{array}$ & $0.68 \mathrm{mg} / \mathrm{mL}$ & LQAFEPLR & {$[11,21]$} \\
\hline Oat bran & Papain & $\approx 1.25 \mathrm{mg} / \mathrm{mL}$ & & & & [48] \\
\hline $\begin{array}{l}\text { Buckwhea } \\
\text { t }\end{array}$ & SGID, trypsin & $1.98 \mathrm{mg} / \mathrm{mL}$ & & & & [11] \\
\hline Rice & Denazyme AP & $1.45 \mathrm{mg} / \mathrm{mL}$ & & & $\begin{array}{l}\text { Identified peptides with } \\
\text { DPP-IV } \quad \text { inhibitory } \\
\text { sequences: Ile-Pro, Met- } \\
\text { Pro, Val-Pro and Leu-Pro. }\end{array}$ & [14] \\
\hline Rice & SGID & $1.85 \mathrm{mg} / \mathrm{mL}$ & & & & [49] \\
\hline Rice bran & $\begin{array}{l}\text { Umamizyme G, } \\
\text { bioprase SP }\end{array}$ & $\begin{array}{l}2.3 \mathrm{mg} / \mathrm{mL} \\
26.4 \mathrm{mg} / \mathrm{mL}\end{array}$ & & & $\begin{array}{lr}\text { Identified } & \text { peptides with } \\
\text { DPP-IV } & \text { inhibitory } \\
\text { sequences: } & \text { Leu-Pro, Ile- } \\
\text { Pro. } & \end{array}$ & [16] \\
\hline Quinoa & $\begin{array}{l}\text { Papain, microbial } \\
\text { papain-like } \\
\text { enzyme }\end{array}$ & $\begin{array}{l}0.88-0.98 \\
\mathrm{mg} / \mathrm{mL}\end{array}$ & & & & [36] \\
\hline Quinoa & SGID & $0.23 \mathrm{mg} / \mathrm{mL}$ & $\begin{array}{l}\text { Ultrafiltration } \\
(<5 \mathrm{kDa}) \\
\rightarrow \text { HPLC }\end{array}$ & $\begin{array}{l}0.31 \mathrm{mg} / \mathrm{mL} \\
\rightarrow 0.41 \\
\mathrm{mg} / \mathrm{mL}\end{array}$ & IQAEGGL & [13] \\
\hline $\begin{array}{l}\text { Highland } \\
\text { barley }\end{array}$ & SGID, trypsin & $3.91 \mathrm{mg} / \mathrm{mL}$ & & & & [11] \\
\hline $\begin{array}{l}\text { Brewer's } \\
\text { spent } \\
\text { (barley) }\end{array}$ & $\begin{array}{l}11 \text { commercial } \\
\text { enzymes }\end{array}$ & $\begin{array}{l}\text { Inhibition rate: } \\
75 \% \\
(3.5 \mathrm{mg} / \mathrm{mL})^{*}\end{array}$ & & & & [25] \\
\hline Amaranth & SGID & & & $1.1 \mathrm{mg} / \mathrm{mL}$ & & [9] \\
\hline Amaranth & Alcalase & & & $0.12 \mathrm{mg} / \mathrm{mL}$ & & {$[50]$} \\
\hline Corn germ & $\begin{array}{l}\text { Flavourzyme } \\
\text { trypsin, alcalase }\end{array}$ & $\begin{array}{l}\text { Inhibition rate: } \\
34.5-45.7 \% \\
(5 \mathrm{mg} / \mathrm{mL})^{*}\end{array}$ & $\begin{array}{l}\text { Ultrafiltration } \\
(2,10 \mathrm{kDa})\end{array}$ & $\begin{array}{l}\text { No } \\
\text { significant } \\
\text { increase }\end{array}$ & & [47] \\
\hline
\end{tabular}

The DPP-IV $\mathrm{IC}_{50}$ of synthetic peptide LQAFEPLR, derived from oat globulin, was $103.5 \mu \mathrm{M}$ [11]. The inhibitory activity of synthetic peptides CPA and FEPL, derived from oat protein, at $1 \mathrm{mg} / \mathrm{mL}$, was $22.2 \%$ and $13.1 \%$, respectively [20]. The inhibitory activity of synthetic peptide IQAEGGLT, derived from quinoa protein, against the DPP-IV enzyme at $250 \mu \mathrm{M}$ was $17.05 \%$ [13]. peptides may also demonstrate certain inhibitory activity [32]. As shown in Table 2, peptides exhibiting DPP-IV inhibitory activity in cereal and pseudocereal protein hydrolysates were primarily identified by whether they contained Pro, while studies on other inhibitory mechanisms were rarely revealed. 
increase in blood glucose after meals caused by carbohydrate intake in normal rats. The mechanisms may be related to the inhibition of DPP-IV activity and the secretion of GLP-1 and insulin secretion. Studies have shown that the oral administration of protein hydrolysates derived from rice bran and endosperm protein can promote GLP-1 and insulin secretion. The intraperitoneal injection of rice protein hydrolysate can inhibit the activity of the DPP-IV and improve the ratio of active GLP/total GLP [38]. Zein hydrolysate in the jejunum or ileum directly stimulates GLP-1 secretion but duodenal zein hydrolysate indirectly stimulates GLP-1 secretion via the vagal afferent nerve [39]. In addition, ileal administration of corn protein hydrolysate can both promote GLP-1 secretion and inhibit GLP-1 degradation, resulting enhancement of insulin secretion and prevention of hyperglycaemia in rats [40]. Moreover, cereal protein hydrolysates may exert long-term glycaemic control through anti-inflammatory effects. Rice protein hydrolysates can alleviate blood glucose, lipid, and insulin levels, as well as insulin resistance in rats fed with carbohydrate-high fat diet. The amelioration of insulin resistance is associated with modulation of adipokine secretions, upregulation of
PPA- $\gamma$ and decreased levels of lipogenesis and proinflammatory cytokines [41]. Wheat and corn peptides can reduce blood glucose in STZ-induced diabetic C57BL/6J mice [42]. At the same time, wheat and corn peptides can delay the initiation and decreased the incidence of diabetes in NOD diabetic mice $[42,43]$. The mechanisms are associated with increase insulin content and the $\beta$ cell area in NOD diabetic mice, while reducing islet inflammation and serum IL-6 levels [42, 43]. It was suggested that hypoglycaemic effects of wheat and corn peptides are associated with their antiinflammatory effects, but not with their antioxidant effect [43]. However, some studies have shown that glucose regulation by cereal peptides may be related to the antioxidant effect. Boonloh et al. believed that rice protein hydrolysates could decrease elevated fasting serum glucose, improve blood lipid profile, alleviate insulin resistance, as well as the progress of diabetic nephropathy and renal function of $\mathrm{db} / \mathrm{db}$ mice by restoring their antioxidant and cytoprotective systems [44].

Table 3 In vivo hypoglycemic activities of protein hydrolysates and peptides from cereals and pseodocereals

\begin{tabular}{|c|c|c|c|c|c|}
\hline $\begin{array}{l}\text { Protein } \\
\text { source }\end{array}$ & $\begin{array}{l}\text { Hydrolysis and } \\
\text { fractionation } \\
\text { method }\end{array}$ & Animal model & $\begin{array}{l}\text { Intervention } \\
\text { method }\end{array}$ & Anti-diabetic activities and mechanisms & Reference(s) \\
\hline Wheat germ & $\begin{array}{l}\text { Trypsin } \rightarrow \\
\text { Ultrafiltration } \\
(<5 \mathrm{kDa})\end{array}$ & $\begin{array}{l}\text { Alloxan induced } \\
\text { type } 2 \text { diabetic } \\
\text { mice }\end{array}$ & $\begin{array}{l}48.6 \mathrm{mg} / \mathrm{kg} \\
2 \text { weeks }\end{array}$ & Fast blood glucose $\downarrow$, diabetic symptoms $\downarrow$. & [17] \\
\hline \multirow{2}{*}{$\begin{array}{l}\text { Wheat and } \\
\text { corn } \\
\text { peptides }\end{array}$} & & $\begin{array}{l}\text { STZ induced } \\
\text { diabetic mice }\end{array}$ & $\begin{array}{l}500 \mathrm{mg} / \mathrm{kg} \\
10 \text { weeks; }\end{array}$ & Hyperglycemia homeostasis $\uparrow$. & [42] \\
\hline & Gel filtration & $\begin{array}{l}\text { NOD type } 1 \\
\text { diabetic mice }\end{array}$ & $\begin{array}{l}125-500 \\
\mathrm{mg} / \mathrm{kg} \\
25 \text { weeks }\end{array}$ & $\begin{array}{l}\text { Delayed initiation of diabetes, OGTT } \uparrow \text {; } \\
\text { serum interleukin (IL)- } 6 \downarrow \text {. }\end{array}$ & \\
\hline $\begin{array}{l}\text { Mixture of } \\
\text { wheat and } \\
\text { corn } \\
\text { peptides }\end{array}$ & & $\begin{array}{l}\text { NOD type } 1 \\
\text { diabetic mice }\end{array}$ & $\begin{array}{l}125 \mathrm{mg} / \mathrm{kg} \\
25 \text { weeks }\end{array}$ & $\begin{array}{l}\text { Delayed initiation of diabetes, incidence } \\
\text { of diabetes } \downarrow \text {, OGTT } \uparrow, \text { IL- } 6 \downarrow \text {, insulitis } \\
\downarrow, \beta \text {-cell area } \uparrow, \text { IL-10 } \uparrow\end{array}$ & [43] \\
\hline Oat & $\begin{array}{l}\text { Alaclase } \rightarrow \\
\text { Ultrafiltration } \\
(<5 \mathrm{kDa})\end{array}$ & $\begin{array}{l}\text { STZ induced } \\
\text { diabetic mice }\end{array}$ & $\begin{array}{l}250-1000 \\
\mathrm{mg} / \mathrm{kg} \\
4 \text { weeks }\end{array}$ & $\begin{array}{l}\text { Fast blood glucose } \downarrow \text {, food efficiency } \uparrow \text {, } \\
\text { insulin } \uparrow, \text { insulin activity } \uparrow \text {, hepatic } \\
\text { glycogen } \uparrow .\end{array}$ & [51] \\
\hline $\begin{array}{l}\text { Commercial } \\
\text { oat } \\
\text { oligopeptides }\end{array}$ & & $\begin{array}{l}\text { STZ induced } \\
\text { diabetic mice }\end{array}$ & $\begin{array}{l}250-2000 \\
\mathrm{mg} / \mathrm{kg} \\
12 \text { weeks }\end{array}$ & $\begin{array}{l}\text { Fast blood glucose } \downarrow \text {, OGTT-AUC } \downarrow \text {, insulin } \\
\text { resistance } \downarrow \text {, antioxidant properties } \uparrow \text {. }\end{array}$ & [52] \\
\hline Rice & Protease G6 & $\begin{array}{l}\text { High } \\
\text { carbohydrate and } \\
\text { high fat fed rats }\end{array}$ & $\begin{array}{l}100-500 \\
\mathrm{mg} / \mathrm{kg} \\
6 \text { weeks }\end{array}$ & $\begin{array}{l}\text { Blood glucose } \downarrow \text {, lipid } \downarrow \text { insulin } \downarrow \text {, insulin } \\
\text { sensitivity } \uparrow \text {, adiponectin } \uparrow \text {, leptin } \downarrow \text {, } \\
\text { inflammatory factors } \downarrow \text {. }\end{array}$ & [41] \\
\hline Rice & Protease G6 & $\begin{array}{l}\mathrm{db} / \mathrm{db} \text { diabetic } \\
\text { mice }\end{array}$ & $\begin{array}{l}100-500 \\
\mathrm{mg} / \mathrm{kg} \\
8 \text { weeks }\end{array}$ & $\begin{array}{l}\text { Insulin sensitivity } \uparrow \text {, fasting serum glucose } \downarrow \text {, } \\
\text { lipid levels } \downarrow \text {, nephropathy } \downarrow \text {, renal function } \uparrow \text {. }\end{array}$ & [44] \\
\hline
\end{tabular}




\begin{tabular}{|c|c|c|c|c|c|}
\hline $\begin{array}{l}\text { Buckwheat } \\
\text { and wheat }\end{array}$ & $\begin{array}{l}\text { SGID } \rightarrow \\
\text { Gel filtration }\end{array}$ & Normal rat & $300 \mathrm{mg} / \mathrm{kg}$ & $\begin{array}{l}\text { Postprandial plasma glucose by starch } \\
\text { loading } \downarrow \text {, postprandial plasma insulin by } \\
\text { starch loading } \downarrow \text {. }\end{array}$ & [8] \\
\hline Rice & Papain, pepsin & Normal rat & $\begin{array}{l}100-2000 \\
\mathrm{mg} / \mathrm{kg} \text { (oral } \\
\text { administration) } \\
; 500 \mathrm{mg} / \mathrm{kg} \\
\text { (ileal } \\
\text { administration) }\end{array}$ & $\begin{array}{l}\text { Oral administration: postprandial glycemia } \\
\downarrow \text {, plasma GLP- } 1 \uparrow \text {; ileal administration: } \\
\text { DPP-IV activity } \downarrow \text {, ratio of active GLP- } \\
\text { 1/total GLP- } 1 \uparrow\end{array}$ & {$[38]$} \\
\hline Maize & Papain & Normal Rat & $\begin{array}{l}200-500 \mathrm{mg} \\
\text { (duodenal, } \\
\text { jejunal, and } \\
\text { ileal } \\
\text { administration) }\end{array}$ & GLP-1 secretion $\uparrow$ & [39] \\
\hline Maize & Papain & Normal rat & $2000 \mathrm{mg} / \mathrm{kg}$ & $\begin{array}{l}\text { Postprandial plasma glucose } \downarrow \text {, insulin } \\
\text { secretion } \uparrow \text {, plasma DPP-IV activity } \downarrow \text {, } \\
\text { GLP-1 secretion } \uparrow \text {, GLP-1 degradation } \downarrow \text {. }\end{array}$ & {$[40]$} \\
\hline Amaranth & Alaclase & $\begin{array}{l}\text { STZ induced } \\
\text { diabetic rat }\end{array}$ & $300 \mathrm{mg} / \mathrm{kg}$ & Glucose tolerance $\uparrow$ & {$[50]$} \\
\hline
\end{tabular}

\subsection{Exploring the regulatory mechanisms of glucose metabolism via cell experiments}

Few studies exist regarding the mechanisms of cereal protein hydrolysates and peptides in regulating blood glucose at the cellular level. Studies have reported that the cereal proteins and peptides can regulate glucose metabolisms by inhibiting DPP-IV activity in Caco-2 cells[11], stimulating GLP-1 secretion in GLUTag cells $[38,39]$, and promoting glucose absorption in insulin resistant HepG2 cells [45]. Oat peptides $(5-20 \mathrm{mg} / \mathrm{mL})$ not only effectively inhibit the DPP-IV activity in Caco2 cells, but also inhibit the expression of DPP-IV [11]. Protein hydrolysates from rice endosperm and bran (10 $\mathrm{mg} / \mathrm{mL})$ [38] and from corn $(5-20 \mathrm{mg} / \mathrm{mL})$ [39] stimulate GLP-1 secretion in GLUTag cell. Rice protein hydrolysates $(400 \mu \mathrm{g} / \mathrm{mL})$ can promote the glucose utilization in insulin resistant HepG2 cells induced by high glucose and IL-6 by suppressing inflammatory cytokine signalling and activates AMPK [45]. Other studies have shown that wheat and corn peptides reduce the inflammation of MIN-6 cells induced by LPS. Their anti-inflammatory abilities may contribute to the delay of type 1 diabetes development [42]. Therefore, the current studies involving in the regulatory mechanisms of glucose metabolism by protein hydrolysates and peptides from cereals and pseudocereals are relatively limited. A lack of scientific evidence remains regarding the molecular mechanisms directly related to glucose metabolism regulation at the cellular level.

\section{Conclusions}

Currently, protein hydrolysates and peptides isolated from rice, wheat, oats, buckwheat, quinoa, barley, and corn have anti-diabetic effects. Due to the high intake of cereal and pseudocereal proteins, the development of anti-diabetic peptides from cereals and pseudocereals have important implications for the dietary prevention and control of diabetes. However, compared with other food-derived peptides, cereal and pseudocereal protein hydrolysates and peptides have not been extensively studied regarding the molecular mechanisms of glucose metabolism. In addition, in terms of peptide absorption, in vivo bioavailability requires further systematic researches. The relationship between the structural characteristics and hypoglycaemic activities of cereal and pseudocereal peptides are still needed to be elucidated, which will provide accurate and valuable information for the development of functional, active peptides from cereals and pseudocereals.

\section{Acknowledgement}

The research was supported by research program of department of education from Fujian province (JAT170696); Research program of Xiamen Medical College(K2016-35); Xiamen Medical College Undergraduate Innovation and Entrepreneurship Training Program (202012631002).

\section{References}

1. S. Kahn, M. Cooper, S. Prato, Lancet 383, 1068 (2014)

2. Y. Zheng, S. Ley, F. Hu, Nat. Rev. Endocrinol. 14, 88 (2017)

3. N. Esser, S. Legrand-Poels, J. Piette, A. Scheen, N. Paquot, Diabetes Res. Clin Pr. 105, 141 (2014)

4. L. Rochette, M. Zeller, Y. Cottin, C. Vergely, Biochem. Biophys. Acta. 1840, 2709 (2014)

5. R. Esfandi, M. Walters, A. Tsopmo, Heliyon 5, e01538 (2019)

6. Y. Liu, P. Strappe, W. Shang, Z. Zhou, Crit. Rev. Food Sci. 59, 349 (2019) 
7. Y. Choi, K. Osada, Y. Ito, T. Nagasawa, M. Choi, N. Nishizawa, Biosci. Biotech. Bioch. 69, 31 (2005)

8. K. Ninomiya, S. Ina, A. Hamada, Y. Yamaguchi, M. Akao, F. Shinmachi, H. Kumagai, H. Kumagai, Nutrients 10, 1503 (2018)

9. A. Velarde-Salcedo, A. Barrera-Pacheco, S. LaraGonzález, G. Montero-Morán, A. Díaz-Gois, E. de Mejia, A.Rosa, Food Chem. 136, 758 (2013)

10. C. Uraipong, J. Zhao, J. Sci. Food Agr. 96, 1101 (2016)

11. F. Wang, G. Yu, Y. Zhang, B. Zhang, J. Fan, J. Agric. Food Chem. 63, 9543 (2015)

12. A. Nongonierma, M. Hennemann, S. Paolella, R. Fitzgerald, Food Funct. 8, 2249 (2017)

13. R. Vilcacundo, C. Martínez-Villaluenga, B. Hernández-Ledesma, J. Funct. Foods 35, 531 (2017)

14. T. Hatanaka, M. Uraji, A. Fujita, K. Kawakami, Int. J. Pept. Res. Ther. 21, 479 (2015)

15. C. Uraipong, J. Zhao, J. Sci. Food Agr. 98, 758 (2018)

16. T. Hatanaka, Y. Inoue, J. Arima, Y. Kumagai, H. Usuki, K. Kawakami, M. Kimura, T. Mukaihara, Food chem. 134, 797 (2012)

17. Y. Hui, Q. Zhang, M. Jiang, S. Zhu, X. Nie, Y. Yu, J. Zhang, J. Jia, M. Xiong, Food Sci. 39, 103 (2018)

18. M. Gänzle, J. Loponen, M. Gobbetti, Trends Food Sci. Tech. 19, 513 (2008)

19. J. Obaroakpo, L. Liu, S. Zhang, J. Lu, X. Pang, J. Lv, Food chem. 299, 124985 (2019)

20. S. Bleakley, M. Hayes, N. O'Shea, E. Gallagher, T Lafarga, Foods 6, 108 (2017)

21. F. Wang, Y. Zhang, T. Yu, J. He, J. Cui, J. Wang, X. Cheng, J. Fan, J. Funct. Foods 42, 12 (2018)

22. P. Patil, S.K. Tomar, S. Anand, Eur. J. Nutr. 54, 863 (2015)

23. G. Derosa, P. Maffioli, Arch. Med. Sci. 8, 899 (2012)

24. C. Levetan, Curr. Med. Res. Opin. 23, 945 (2007)

25. A. Connolly, C. Piggott, R. FitzGerald, Food Res. Int. 56, 100 (2014)

26. F. Wang, Y. Zhang, T. Yu, J. He, J. Cui, J. Wang, X. Cheng, J. Fan, J. Funct. Foods 42, 11 (2018)

27. W. Yu, W. Zou, S. Dhital, P. Wu, M. Gidley, G. Fox, R. Gilbert, Food Chem. 241, 493 (2017)

28. C. Chi, X. Li, Y. Zhang, L. Chen, L. Li, Food Hydrocolloid 84, 473 (2018)

29. H. Lin, L. Lin, Y. Tian, X. Zhang, B. Li, Adv. Mat. Res. 138, 581 (2012)

30. C. Uraipong, J. Zhao, Int. J. Food Sci. Tech. 51,2201 (2016)

31. M. Ibrahim, M. Bester, A. Neitz, A. Gaspar, Chem. Biol. Drug Des. 91, 370 (2018)
32. O. Power, A. Nongonierma, P. Jakeman, R. Fitzgerald, Proc. Nutr. Soc. 73, 34 (2014)

33. H. Umezawa, T. Aoyagi, K. Ogawa, H. Naganawa, M. Hamada, T. Takeuchi, J. Antibiot. 37, 422 (1984)

34. I. Lacroix, E. Li-Chan, J. Funct. Foods 4, 403 (2012)

35. I. Lacroix, E. Li-chan, Trends Food Sci. Tech. 54, 1 (2016)

36. A. Nongonierma, S. Maux, C. Dubrulle, C. Barre, R. FitzGerald, J. Cereal Sci. 65, 112 (2015)

37. A. Nongonierma, R. FitzGerald, J. Food. Biochem. 43, e 12451 (2019)

38. Y. Ishikawa, T. Hira, D. Inoue, Y. Harada, H. Hashimoto, M. Fujii, M. Kadowaki, H. Hara, Food Funct. 6, 2525 (2015)

39. T. Hira, T. Mochida, K. Miyashita, H. Hara, Am. J. Physiol. Gastrointest. Liver Physiol. 297, 663 (2009)

40. T. Mochida, T. Hira, H. Hara, Endocrinology 151, 3095 (2010)

41. K. Boonloh, V. Kukongviriyapan, B. Kongyingyoes, U. Kukongviriyapan, S. Thawornchinsombut, P. Pannangpetch, Nutrients 7 , 6313 (2015)

42. S. Sun, H. Zhang, K. Shan, T. Sun, M. Lin, L. Jia, Y. Chen, Mol. Nutr. Food Res. 63, 1800987 (2019)

43. S. Sun, G. Zhang, H. Mu, H. Zhang, Y. Chen, J. Funct. Foods 56, 163 (2019)

44. K. Boonloh, E. Lee, H. Kim, M. Kwon, Y. Kim, P. Pannangpetch, B. Kongyingyoes, U. Kukongviriyapan, S. Thawornchinsombut, E. Lee, V. Kukongviriyapan, C. Chung, Eur. J. Nutr. 57, 761 (2018)

45. K. Boonloh, U. Kukongviriyapan, P. Pannangpetch, B. Kongyingyoes, L. Senggunprai, A. Prawan, S. Thawornchinsombut, V. Kukongviriyapan, Food Funct. 6, 566 (2015)

46. Y. Zhang, R. Chen, F. Zuo, H. Ma, Y. Zhang, S. Chen, Int. Dairy J. 53, 37 (2016)

47. A. Karimi, M. H. Azizi, H. Gavlighi, Food Sci. Nutr. 8, 2395-2405 (2020)

48. M. Walters, W. Willmore, A. Tsopmo, Antioxidants 9, 557 (2020)

49. A. Nongonierma, R. FitzGerald, Curr. Opin. Food Sci. 6, 19 (2015)

50. S. Jorge, R. Raúl, G. Isabel, P. Edith, E. Bernardo, A. César, D. Gerardo, R. Rubén , Afr. J. Tradit. Complem. 12, 90 (2015)

51. H. Zhang, J. Wang, Y. Liu, B. Sun, J. Biomed Sci 4, 1 (2015)

52. J. Wang, X. Liu, S. Liu, R. Mao, C. Hou, N. Zhu, R. Liu, H. Ma, Y. Li, Molecules 24, 558 (2019) 